Discourse and Communication for Sustainable Education, vol. 7, no. 2, pp. 34-42, 2016

\title{
Delving Into Key Dimensions of ESD Through Analyses of a Middle School Science Textbook
}

\author{
Elvan Sahin \\ Middle East Technical University, Turkey
}

\begin{abstract}
Uncertainties and debates regarding the term of sustainable development are still going on, and similarly, the notion of education for sustainable development (ESD) is open to debate. There has been an attempt to make the concept of ESD evident, which is quite challenging. Palmer (1998) stated the appropriateness of ESD within environmental education and presented ESD as a new trend for teaching and learning about the environment. In line with these interpretation, Sauvé (2002) pointed out that ESD seems to emerge as a current issue within environmental education. Contrary to these claims, some researchers do not interpret ESD as an evolution within environmental education. According to Sterling (2001), ESD can be recognized as sustainable education in which there is a movement toward the renewal of education systems and institutions 'doing better things' and 'seeing things differently'. Apart from those qualitatively different interpretations of ESD, in 1998 the Council for Environmental Education published a strategy report (CEE, 1998) which is particularly significant for teachers. This report specified seven key dimensions regarding ESD, namely: interdependence; citizenship and stewardship; needs and rights of future generations; diversity; quality of life, equity and justice; sustainable change; and uncertainty and precaution in action. This study could provide an analysis of Turkish middle school science textbooks with respect to these key dimensions on ESD. Current evidences showed that these textbooks do not refer to the dimensions of sustainable development sufficiently.
\end{abstract}

Keywords: education for sustainable development, middle school science education, sustainable use of natural resources

\section{The Vision of Sustainable Development}

We have utilized human-centric approaches to understand our value, our place and role within the biological systems. Such an approach overemphasizing humanbeings has brought about depletion of natural resources, damage to natural environment and created a challenging issue to the long-term sustainability of our planet, the earth (Tillmanns, Holland, Lorenzi, and McDonagh, 2014).

The concept of sustainability was first introduced by a Western environmentalist in the World Council of Churches in 1974 (World Council of Churches, 1974). It was emerged as a result of feelings of concern toward the environment when human beings 
in many parts of the world suffer from extreme poverty, lack of fresh water, or discrimination. Sustainability accompanied by sustainable development became a central issue when the United Nations' World Commission on Environment and Development published its report called Our Common Future (World Commission on Environment and Development, 1987). The key point behind this report that was originated from competitive demands for environmental protection and economic development was actually a new approach: sustainable development. It was reported that sustainable development was dealing with both equity between generations and equity within generations.

The definition WCED suggested: "Sustainable development is development which meets the needs of the present without comprising the ability of future generations to meet their own needs" (WCED, 1987, p. 43). The brief definition of sustainable development by WCED implies that human needs are basic and essential. Furthermore, economic development accompanied by equity to share resources with poor nations should be maintained and the equity should be encouraged by effective citizen participation. Until the recent years, the literature review (e.g Kates, Parris and Leiserowitz, 2005) has pointed out the unclear points of the standard definition of sustainable development.

Governments, non-governmental organizations, and international agencies quickly got used to the term "sustainable development". Since United Nations Conference on Environment and Development (UNCED) which took place in Rio de Janeiro in 1992, the terms "sustainability" and "sustainable development" have been used interchangeably (UNCED, 1992).

To understand the core idea behind "sustainability", every individual has to know why our world is truly unsustainable and what the indicators are which show that our world is unsustainable. Unsustainability has diverse affects on different aspects of our life. Thus, the need for active engagement of every individual towards sustainability is very urgent.

In 2004, Webster stressed that global or local unsustainability trends could not be considered just about environment or nature; but it also deals with social conditions, politics, and the economy as well. Increasing wealth has been accompanied by increasing inequality, both within nations and regions, and in the world as a whole. Thus, many serious health and welfare issues have been placed among the current issues worldwide. In rich nations, wealth has been accompanied by increasing crime, drug, and alcohol abuse, mental health problems. The 2030 Agenda for Sustainable Development (UN, 2015) has affirmed that billions of people continue to live in poverty and inequalities within and among countries are still rising. Gender inequality and youth unemployment has been regarded as great challenge. Depletion of natural resources, adverse consequences of environmental degradation covering the long list of challenges (e.g loss of biodiversity, desertification, drought, global warming, fresh water scarcity) that we suffer are among the threats to the survival of many societies and of the biological support systems.

To overcome the problems emerging with unsustainability trends, education and educational cooperation has been viewed as an important factor in the resolution of the problems regarding these global and local trends. A worldwide action plan, namely Agenda 21 accepted at the Earth Summit in 1992 proposed that education is critical for promoting sustainable development and improving the capacity of the people to address sustainable development issues (UNCED, 1992). A later document, the World Summit on Sustainable Development in Johannesburg also points out the importance of education to meet the basic needs of all including the future generations (WSSD, 2002). 


\section{Education for Sustainable Development}

Not only are uncertainties and confusions regarding the concept of sustainable development still going on, but also the notion of education for sustainable development (ESD) is similarly open to debate. Pertinent to sustainable development, the literature extensively reported what should be taught and learned in the context of knowledge, skills and values that could aid in attaining the major goals of sustainable development (Makrakis and Kostoulas-Makrakis, 2012). There has been an attempt to make the concept of education for sustainable development evident, which is quite challenging. According to some researchers (e.g. Sauvé, 2002), ESD seems to emerge as a current issue within environmental education. This idea was supported by Fien (1993) and Huckle (1993) who indicated an emphasis on issues of sustainability evolving through the prioritization of the understanding of social, political and economic influences on the environment and enhancement of children's awareness, emotional bonding to nature, and responsible actions. In line with these interpretations, Palmer (1998) stated the appropriateness of ESD within environmental education and presented ESD as a new trend for teaching and learning about the environment.

On contrary to these suggestions, some researchers do not interpret ESD as an evolution within environmental education. This may be due to another point of view that gives priority to physical environment and issues such as human impact, preservation and conservation of the nature through environmental education. According to Sterling (2001), ESD can be recognized as sustainable education in which there is a movement toward the renewal of education systems and institutions 'doing better things' and 'seeing things differently'. Apart from those qualitatively different interpretations of ESD, in 1998 the Council for Environmental Education published a strategy report (CEE, 1998) titled with 'Education for Sustainable Development in the Schools Sector' in Sustainable Development Education Panel (SDEP) that is particularly significant for teachers. ESD was defined in this report (p.3) in the following way:

\section{"Education for sustainable development enables people to develop the know- ledge, values, and skills to participate in decisions about the way we do things individually and collectively, both globally and locally, that will improve the quality of life now and without damaging the planet for the future".}

The report was written by some educators assigned by the government of England and Wales where sustainable development was placed in the revised National Curriculum for the year 2000. It also serves for learning outcomes reflecting each key spheres of ESD. Since there is little exemplification of teaching practices regarding ESD, the researchers (Summers and Kruger, 2003; Summers, Corney and Childs, 2003) which focused on English primary school teachers' reflections on each dimensions of sustainable development into classroom teaching has a great contribution to our knowledge base. Not paying special attention to the complexities and ambiguities stated in the context of the definition of sustainable development, Summers and Kruger (2003) chose to develop a professional development programme considering ESD and the views expressed in the CEE report. The seven CEE key dimensions of sustainable development were presented as a framework in order to aid in developing an understanding of the sustainability of any human activity, and were depicted by demonstrating how they might apply to a particular issue (species loss). Thus, after a preparation period for teachers' professional development on ESD, the participants of this program proposed some examples for 
their teaching practices on dimensions of sustainable development (see Table 1) (Summers and Kruger, 2003, p. 169). These authors inferred from the content and teaching strategies included in teachers' classroom activities that they could interpret ESD in line with CEE framework. Furthermore, they evaluated the teachers' views from the perspective of Sauvé (1996). Sauvé has considered the connection between the fundamental elements of ESD and conceptions of environmental education. The educator emphasized that ESD has evolved as a result of a need to update the environmental education discourse through the consideration of the needs and rights of human beings as an integral part of the ecosystem. Hopefully from this perspective, these teachers' conceptions of ESD strongly depended on the citizenship and stewardship covering the importance of taking responsibility, human action, and making a difference. Furthermore, they viewed sustainable development holistically in terms of social, economic and environmental factors. They aimed to engage the pupils in both social and economical issues utilizing the perspectives of people from different communities. To make clear conceptualizations of sustainable development in the wider community of primary school teachers, case-study examples covered in CEE report for classroom practice may not be sufficient. For this reason, Summers and Kruger (2003) recommended that appropriate professional development programs may support in interpreting the dimensions of ESD reported in CEE.

Table 1

Exemplifications of ESD Generated by Primary School Teachers (Summers \& Kruger, 2003; p. 169)

CEE Framework Dimensions \& Selected examples from primary school teachers in teaching

\section{Interdependence}

people, the environment and the economy are linked at all levels from local to global

- Brazilian rainforests are valuable sources used in western medicine

- Global warming from our burning of fossil fuels may contribute to floods in Bangladesh

- The common blue butterfly needs grassland grazed by sheep to survive

2. Citizenship and stewardship

the importance of taking individual responsibility and action to ensure the world is a better place

- Things can be done to make the school environment better for animals, plants and

ourselves, e.g. creating a 'wild' area or planting 'butterfly-friendly' plants

- Children can co-operate with others to take energy saving measures in school

- Individuals can make a difference to the problem of waste by using the '4 Rs' (reduce, reuse, repair, recycle)

\section{Needs and rights of future generations}

our own basic needs and the implications for the needs of future generations of actions taken today

- Utilizing more sustainable and less wasteful energy related actions and products conserves finite energy sources for use by those who come after us

- Our children (and their children) have a right to see wild tigers in their natural habitat

\section{Diversity}

respecting and valuing both human diversity - cultural, social and economic - and

biodiversity

- The variety of species of fish and insects in a river is a measure of water purity

- The rainforest environment can sustain an enormous range of plants and animals, many of which have beneficial uses to humanity - what others remain undiscovered? 
Sequel to Table 1.

5. Quality of life, equity and justiceglobal equity and justice are essential elements of sustainability and basic needs must be met universally

- A home, water and energy are universal basic needs which are not equally available to all

- People of more economically developed countries have an ecological footprint greater than the earth share only at the expense of other less fortunate people in less economically developed countries

6. Sustainable change (development and carrying capacity)

understanding that resources are finite and that this has implications for people's lifestyles, and forcommerce and industry

- Burning fossil fuels releases carbon dioxide into the environment - this may exceed the amount which is removed by photosynthesis, leading to global warming

- The need for landfill sites for waste disposal is not matched by the availability of suitable land

7. Uncertainty and precaution in action

there are a range of possible approaches to sustainability and situations are constantly changing, indicating a need for flexibility and lifelong learning

- Every species in an ecosystem, such as a rainforest, must be valued since we are unsure of the knock-on effects of a species' removal on food chains in the system as a whole

- People can have different views on sustainability issues to do with water which may be in conflict - such as the views of professional fishermen and scientists about catch quotas

In recent years, the discussion about sustainability and education for sustainable development has shifted from search for a universal consensus to a position where there is an acceptance of varying definitions and approaches (Scott and Oulton, 1999). Furthermore, Sauvé (1996) supported this view with emphasizing the role of different paths resulting with the desired outcome that can also serve for the concept of sustainable development. According to Scott and Gough (2003), lifelong learning is the key element in sustainable development and it can be a process - not an end state. Sustainability can be thought as a paradigm for the sake of a future in which environmental, social and economic aspects are balanced in order to endeavor for improved quality of life. During this process, interaction with people from different point of view seems to work well in learning more about sustainability.

\section{An Exemplification of ESD Applications from a Currently Used Textbook in Turkey}

ESD efforts undertaken to be able to create a more sustainable future have potential to yield more favorable outcomes when addressed at pupils and young people (Buttigiet and Pace, 2013). This may imply that we should not neglect the ESD efforts towards young people by integrating sustainability issues with appropriate pedagogies. Recently, in order to integrate sustainability issues into curriculum in various diciplines, the common approach followed in different settings has been using the concept as an extra topic; adding a lecture or module to the curriculum (Armstrong, LeHew, 2011). Following a similar trend, in 2013, a significant emphasis on integrating sustainability issues was placed within middle school science education program and relevant textbooks in Turkey. It was the first time that 'sustainable development' as terminology appeared within formal school education programs although it was previously aimed to integrate sustain- 
ability issues within various programs in this country. Sustainable development has been viewed as 'usage of natural resources by considering the needs of future generations from a perspective of personal and national benefits of using sparingly in terms of society and economy' (MoNE, 2013). With this point of view, some scientific concepts and issues were introduced by constructing a linkage with societal and economic factors in the context of sustainable development. Within the middle school science education program (5-8 grades), the unit of 'Properties of Matter' in seventh grade covered some learning outcomes on the topic of household waste and recycling. The topic of household waste management and recycling could provide a significant opportunity to integrate ESD related vision by considering the CEE framework. Thus, the learning outcomes and the content of the textbook could be analyzed by conducting content analysis.

Some examplifications presented in the middle school science textbook (Ozoglu and Misirlioglu, 2014), in other words some examplifications that could be used in an ESD oriented science instruction in Turkey were presented in Table 2. These examplifications were compared and categorized under the main categories of CEE framework by using a qualitative approach. This part of the current study involved analyzing and synthesizing the information that was obtained from a document as a source into a coherent explanation of what was observed and discovered (Fraenkel and Wallen, 2006). Before the analysis was begun, the categaories were determined based on the previous work. It was found that the provided examples covered in the relevant textbook fell into 'interdependence', 'citizenship and stewardship' dimesions of sustainable development. More specifically, the interdepency among people, the economy, and the environment were stressed in the context of recycling. However, some specific examples showing how recycling in a local setting may contribute to the resolution of a problem also experienced in another country on the planet were among neglected sides of sustainable development in the textbook. While considering the recommended teaching activities, a field trip designating the contribution of chemical industry to the national economy was undertaken. Such an activity modeling outdoor education could be empowered by also emphasizing the impacts of chemical industry on the underground water quality and the strategies to eliminate the negative impacts of these applications.

Table 2

CEE Framework Dimensions \& Examples from the Currently Used Science Textbook (Ozoglu \& Misirlioglu, 2014)

1. Interdependence

people, the environment and the economy are linked at all levels from local to global

- Rapid growth in human population and consumption patterns contribute a rise in waste

- Recycling of 1 tone of paper prevent cutting down of 17 trees

- People working for recycling industry contribute to national economy and also raise family income

- Chemical industry field trip - the contribution of products to the national economy

2. Citizenship and stewardship the importance of taking individual responsibility and action to ensure the world is a better place

- Children co-operate with each other and other people around them to produce some measures to the problem of waste by using recycling and reusing 


\section{Conclusion}

Considering the challenge of sustainable development, education come across with a complex problem which requires a paradigmatic change of course to fortify principles and values coherent with the process of sustainable development. The global crisis we are currently suffering today has emerged as a consequence of the values that have been neglected or even forgotten, by the most developed countries (Cutanda and MurgaMenoyo, 2014). As emphasized by Mifsud (2012), sustainable development is required to be depicted as crucial for all countries and, even more so, in geographically small regions due to the limited natural resource and high population density. In this aspect, Turkey could be considered as a country needed to accelarete its attempts in order to attain sustainable development goals. Based on the current study, we could also consider attaining the learning outcomes regarding recycling and waste management from a broader perspective titling 'sustainable use of natural resources'. In other words, middle school science education defining 'sustainable development' as mentioned above may use 'sustainable use of natural resources' as an umbrella term to raise an awareness, develop values, and skills as well as responbility while focusing on 4R (reducing, reusing, repairing and recycling) model. However, the current situation forces teachers to centralize their teaching around recycling. More importantly, the limitations of recycling process including some restrictions and the need for energy were not covered in the textbook. The concerns orienting around the needs and rights of future generations, diversity, carrying capacity and development, and quality of life, social justice and equity could be handled in the context of 'sustainable use of natural resources' or even 'recycling and waste management'. Reducing and repairing were not emphasized but these measures could be examplified and examined from carrying capacity and developmental perspective. Lastly and the most importantly, the linkage beween climate change perceived and experienced as a global issue and household waste management (Buttigieg and Pace, 2013) does not appear in these scienece textbooks and learning outcomes. However, such a case could be integrated by carefully considering seven key dimensions of sustainable development. At this point, it crucially important to note that professional development programs for teachers should be on-going in ESD process since in-service training of teachers is influcial on sharing updated teaching experiences and provide medium of ESD teaching in formal education (Kabadayi, 2016).

The present study was conducted based on following a path that Summers and Kruger (2003) emphasized previously. On the one hand, it is was reported that the debates on various interpretations of ESD is still going on. On the other hand, Summers and Kruger (2003) evaluated the teaching practices of teachers participating in professional development programs by considering the key dimensions of sustainable development. These authors' interpretations could shed light on developing educational programs on ESD, preparing textbooks, and educating teachers both professionally and personally.

\section{References}

Armstrong, C., \& LeHew, M. (2011). Scrutinizing the explicit, the implicit and the unsustainable: A model for holistic transformation of a course for sustainability. Journal of Teacher Education for Sustainability, 13(2), 17-43.

Buttigieg, K., \& Pace, P. (2013). Positive youth action towards climate change, Journal of Teacher Education for Sustainability, 15(1), 15-47. 
Council for Environmental Education (1998). Education for sustainable development in the schools' sector: A report from the panel for Education for Sustainable Development. Reading: Council for Environmental Education.

Cutanda, G.A., \& Murga-Menoyo, M.A. (2014). Analysis of mythical-metaphorical narratives as a resource for education in the principles and values of sustainability. Journal of Teacher Education for Sustainability, 16(2), 18-38.

Fien, J. (1993). Education for the environment: critical curriculum theorising and environmental education. Geelong: Deakin University Press.

Fraenkel, J. R., \& Wallen, N. E. (2006). How to design and evaluate research in education. Boston: McGraw-Hill.

Huckle, J. (1993). Environmental education and sustainability - a view from critical theory. In J. Fien (Ed.), Environmental education: a pathway to sustainability. Geelong, Deakin University Press.

Kabadayi, A. (2016). A suggested in-service training model based on Turkish preschool teachers' conceptions for sustainable development. Journal of Teacher Education for Sustainability, 18(1), 5-15.

Kates, R. W., Parris, T. M., \& Leiserowitz, A. A. (2005). What is sustainable development? Goals, indicators, values, and practice. Environment, 47(3), 9-21.

Makrakis, V., \& Kostoulas-Makrakis, N. (2012). Course curricular design and development of the M.Sc. programme in the field of ict in education for sustainable development. Journal of Teacher Education for Sustainability, 14(2), 5-40.

Mifsud, M. (2012). Environmental education development in Malta: A contextual study of the events that have shaped the development of environmental education in Malta. Journal of Teacher Education for Sustainability, 14(1), 52-66.

Ministry of National education [MoNE] (2013). İlkögrretim fen bilimleri dersi öğretim programı [Elementary science education program]. Retrieved April 23, 2015, from: http://ttkb.meb.gov.tr

Ozoglu, H.H., \& Misirlioglu, Z. (2014). Ortaokul Fen Bilimleri 7 Ders Kitabı [Middle School science 7 course book]. Ada Matbaacilik Yayincilik San. Ve Tic. Ltd. Ş., Ostim, Ankara.

Palmer, J. (1998). Environmental education for the 21st century. London: Routledge.

Sauvé, L. (1996). Environmental education and sustainable development: a further appraisal. Canadian Journal of Environmental Education, 1, 7-35.

Sauvé, L. (2002). Environmental education: possibilities and constraints. Connect: UNESCO International Science, Technology, and Environmental Education Newsletter, 27, 1-4.

Scott, W., \& Gough, S. (2003). Oral evidence to the House of Commons Environmental audit committee's enquiry into sustainable development. UK: University of Bath.

Scott, W. \& Oulton, C. (1999). Environmental education: arguing the case for multiple approaches. Educational Studies, 25, 89-97.

Sterling, S. (2001). Sustainable education: revisioning learning and change. Totnes, Greenbooks.

Summers, M., Corney, G. \& Childs, A. (2003). Teaching sustainable development in primary schools: an empirical study of issues for teachers. Environmental Education Research, 9, 327-346.

Summers, M., \& Kruger, C. (2003). Teaching sustainable development in primary schools: theory into practice. The Curriculum Journal, 14(2), 157-180. 
Tillmanns, T., Holland, C., Lorenzi, F., \& McDonagh, P. (2014). Interplay of rhizome and education for sustainable development. Journal of Teacher Education for Sustainability, 16(2),5-17.

United Nations (2015). Transforming our world: The Agenda 2030 for sustainable development. Retrieved October 1, 2016, from: https://sustainabledevelopment. un.org/content/documents/7891Transforming Our World.pdf

United Nations Conference on Environment and Development (UNCED) (1992). Agenda 21- Action plan for the next century. UNCED, Rio de Janerio.

Webster, K. (2004). Rethink, refuse, reduce... Education for sustainability in a changing world. Shrewsbury: Field Studies Council Publications.

World Commission on Environment and Development (1987). Our common future. Oxford: Oxford University Press.

World Council of Churches (1974). Report of ecumenical study conference on science and technology for human development. Geneva: World Council of Churches.

WSSD, Key outcomes of the summit (2002). World Summit on Sustainable Development. Retrieved May 1, 2015, from: http://www.johannesburgsummit.org/html/ documents/summitdocs/2009-keyoutcomes-commitments.doc

Correspdence concerning this paper should be addressed to Assoc. Prof. Dr. Elvan Sahin, Middle East Technical University, selvan@metu.edu.tr 